\title{
Long-Term Relationship Building and Customer Switching Behaviour in the Mobile Telecommunication Industry in Nigeria
}

\author{
Ebhote Oseremen ${ }^{1}$
}

\begin{abstract}
This paper examined long-term relationship building and customer switching behavior among mobile telecommunication operators in Nigeria. The population of this study includes all mobile telecommunication company and their subscribers in Edo State, Nigeria. The samples for this study were drawn from Mobile Network Service Providers and their subscribers. For service providers, three (3) out of the nine (9) mobile network operators were selected (Nigeria Communication Commission NCC, 2020). Morgan and Krejcie's (1970) sampling methods were implemented to choose a sample of 322 mobile telecom subscribers Godden (2004). The paper employed regression analysis to analyze and test the bypothesis formulated. The result showed that long-term relationship building (Two-way Communication, Customer retention Strategy, Customer Loyalty, and Relational Bond) had a positive statistically significant relationship with customer switching behavior among mobile telecommunication operators (Network service providers) at $p>0.05$. The research recommends among others that players of the mobile telecommunication Industry (mobile network. service providers) should embrace the application of long-term relationship-building to achieve, sustain and retain customers' usage of their products, this will enable them to compete better with other players in the industry. Also, they should engage in relational bonding aimed at creating attachment with the customer leading to customer retention and subsequently profitability.
\end{abstract}

Keywords: Relationship building, mobile telecommunication., customers, Switching behavior, Nigeria.

JEL Classification: $M 1, M 2, M 3$.

DOI: $10.24818 / \mathrm{REJ} / 2021 / 80 / 02$

\section{Introduction}

Business firms in modern society are increasingly drifted toward building a longstanding relationship with customers in the marketplace. They realize that a sound customer relationship will propel the business on the path of high market share and increased profitability and enable the business to compete favorably alongside its

\footnotetext{
${ }^{1}$ Ph.D., Department of Business Administration, Faculty of Arts Management and Social Sciences, Edo State University Uzairue, Edo State. ebhote.oseremen@edouniversity.edu.ng 
competitor. Competition in the marketplace is invariable what an organization cannot be exempted from, therefore mapping out a relationship strategy that will culminate into customer retention and prevent customer switching which might be costly for the organization is important. Michell (2000) opined that basic customer relationship management theory is as vigorous as ever and as a result, a firm that can encompass its customers in a tradeoff of vital information has obtained an influential tool that will culminate into a scenario where both parties benefit. That engaging in discourse and exchange of ideas with their consumers will aid business establishments to develop a potent, dependable, and mutual engagement.

However, many business organizations have realized that customers could be their unique emissaries. More and more, organizations, therefore, think of long-term relationship building/marketing as a generational friendship with customers. As a viewpoint for posterity one could argue that organizational goal in this aspect should not only be to satisfy the customer but should also establish a policy that will help retain customers in the business. Ranchhod (2004) counsels organizations to make optimum use of customer equity by looking into three main areas as follows: i. value equity which implies a customer's fair evaluation of the efficacy of a product, built on the insights of the worth of the swop process. ii. brand equity which implies customers' independence and predisposition attributed with the variety and beyond their independent assessment of the brand. iii retention equity signifies that an organization's value depends on the lifetime value of its customer comparatively than just its brands and reproduces the significance of the customers as partakers in a business organization.

Customer switching behavior ensues when a customer opts out from their earliest supplier and switch to another service supplier, with the initial provider missing imminent profits and stomaching the expense of gaining novel customers (Keaveney, 1995). Switching behavior also refers to the manner customers change from one provider to another provider. Researchers have shown that switching is bulbous among telecom consumers due to the activities of alternative telecom service providers. Consumers grow their defiance when relative recompenses from a new or existing service provider surpass that of their current telecom service provider. Analyzing the cause behind customers' switch, Gourville (2003) asserts that service users are susceptible to comparative benefits and cost of any modification and will therefore interchange when the new product obtainable encouragingly advance satisfaction than what is presently been presented by the provider. In the background of this study, customer switching behavior implies a modification from one telecom service provider to another in the same industry.

Year XXIV no. 80

June 2021 
The focus of this paper is to examine the effect of long-term relationship building on customer switching behavior among telecom service providers in Nigeria.

Long-term relationship building is a unique aspect of marketing aimed at building a relationship beyond the normal buying and selling that exists between the customers and the business firm rather transcend to knowing the customers completely by further examining their needs and wants and other add-on services the customers may require for proper satisfaction. Some of the factors responsible for the brand switching behavior of consumers hinge on the nature of the business, but generally, poor service quality is a major perpetrator. The Microsoft 2018 State of Global Customer Service Survey observed that about 61\% of respondents had switched brands in response to poor service, and almost half had done so in the past year. The poor-quality services alleged in the above survey as reasons for customer's switching would have been easily detected and improved upon by the organization if they have a sound relationship with their customers. When customers are not satisfied with their current services, the likelihood of switching to other service providers is imminent. Despite several scholarly published works on the above subject matter, many mobile telecommunication service providers are oblivion of this fact by not giving the concept of long-term relationship building it needed attention. Reasons could be that they are not enlightened enough to know that dissatisfied customers will look elsewhere to other providers for satisfaction which is usually referred to as customer switching behavior. Again, it cost more for an organization to acquire new customers than maintaining its existing ones. To this end, therefore, the rationale for this paper is to examine the effect of building a long-term affiliation with customers in averting customers from switching behavior among mobile telecommunication service providers in Nigeria.

The primary objective of this research is to evaluate the effect of long-term relationship building on customer switching behavior among mobile telecommunication service providers in Nigeria. However, long-term relationship building has been decomposed into two-way communication, client retention strategy, customer loyalty, and relational bond. Therefore, the secondary objectives are as follows: To examine the effect of two-way communication on customer switching behavior among mobile telecommunication service providers in Nigeria, to evaluate the effect of customer retention strategy on customer switching behavior among mobile telecommunication service providers in Nigeria, to access the effect of customer loyalty on customer switching behavior among mobile telecommunication service providers in Nigeria. to evaluate the effect of relational bonds on customer switching behavior among mobile telecom providers in Nigeria.

Year XXIV no. 80

June 2021 
The researcher formulated the following hypothesis in a null form to serve as a guide bearing in mind that long-term relationship building has been decomposed into two-way communication, customer retention, customer loyalty, and relational bond.

$\mathrm{Ho}_{1}$ : two-way communication does not prevent customer switching behavior among mobile telecommunication service providers in Nigeria.

$\mathrm{Ho}_{2}$ : customer retention strategy does not prevent customer switching behavior among mobile telecommunication service providers in Nigeria.

$\mathrm{Ho}_{3:} \quad$ customer loyalty does not prevent customer witching behavior among mobile telecommunication service providers in Nigeria.

$\mathrm{Ho}_{4}$ : relational bond does not prevent customer switching behavior among mobile telecommunication service providers in Nigeria.

The scope of this study is restricted to the mobile telecommunication service provider operating in Nigeria with a large customer subscriber base across the nation. as of February. According to the Nigeria Communication Commission NCC (2020), Mobile Telecommunication Network (MTN). Globacom Nigeria (GLO) and Airtel have over a 50million subscribers in Nigeria. The choice of the service provider with a large subscriber base is to enable the researcher to obtain data from customers on service providers with similar competitive strengths. Also, the fact that the listed telecom service providers were established almost at the same time makes it easy to study them together.

This research contributed to existing knowledge by offering an empirical and theoretical explanation of the effect of long-term relationship building on customer switching behavior in the telecommunication industry in Nigeria using regression analyses to unveil the impact of the independent variables on the dependent variables.

The remaining aspect of the paper is designed as follows. Section 2 deliberates on the theoretical framework and testable hypotheses in the light of the existing literature. The research methodology is taken care of by Section 3, furthermore, Section 4 discourses the empirical results and consequent implications. Section 5 looked at future research directions

\section{Literature Review}

\section{Concept of Long-term Relationship building}

Customer long-term relationship building (CRM) as a business process aimed at building client relationships, customer loyalty, and brand value are built through marketing strategies and activities. CRM allows businesses to develop long-term 
relationships with established and new customers while helping streamline corporate performance. CRM incorporates commercial and client-specific strategies via employee training, marketing planning, relationship building, and advertising. Customer relationship marketing focuses on appealing, developing, and ensuring customers stay with the firm as much as possible by providing the needed satisfaction to customers (Berry and Parasuraman 1991). Customer relationship marketing is aimed at enhancing enlarged value to the customer which will emanate into long-term value for the service provider. Ensuring exceptional service quality facilitates the likelihood to establish a prolonged association with end-users. The view of long-term relationship building is valid to numerous industries. It is largely momentous in services due to face-to-face interaction that subsists among suppliers and end-users of products (Liu,Tao, Li and El-Ansary, 2008). Berry (2002) sees relationship marketing as a form of marketing established through response marketing campaigns that underscore customer retention and satisfaction rather than sales transactions. It distinguishes itself from other forms of marketing in that it acknowledges the long-term value of customer relationships and encompasses interaction beyond intrusive advertising and sales promotional messages. Padmavathy Balaji \& Sivakumar (2012) defined CRM as a set of customer-oriented activities braced by organizational strategy and technology and is intended to advance customer communication to build customer loyalty and increase profits over time. Again, enhancing relationships with customers will prevent the switching behaviors of customers and ensure their retention in the business.

\section{Two-way Communication}

Adopting the Push-Pull theory which emphases on the push elements that scare away customers from a company and the Pull factors that might entice a customer to a firm. Staden, Marx \& Erasmus (2002) see communication as one of such pull factors that could attract customers to a firm when they assert that communication is a two-way course by which info is activated from one person called the sender through a channel to another person referred to as the receiver who in turn decodes and reacts to the information by giving feedback. Staffa's of an organization at various levels engage in communication with business contemporaries, clients, bondholders, the media, and the public continuously. There is virtually no organization that can perform its duties efficiently or attains its objectives in the absence of good communication channels. Staden et al. (2002) opined that the following as benefits of communicating properly with customers: better customer relationships, its saves time and money, more actual decision-making, successful problem-solving. Effective communication between a business and its customers will no doubt enhance the activities of the organization and prevent customers

Year XXIV no. 80

June 2021 
switching behavior which is very costly to the organization. Velnampy and Sivesan (2012) in a study on customer relationship marketing and customer satisfaction: A study on mobile service providing companies in Srilanka determined the connection therein between customer relationship marketing (better communication) and customer satisfaction. They measure customer relationship marketing using sets of variables like trust, commitment, empathy, and equity. Data for the study were gathered with the aid of seven points Likert. Kehinde, Adegbuyi, and Borishade (2016) study on relationship marketing: The antidote for effective sales performance in the Nigerian Banking Industry accessed the connection between relationshipmarketing and performance of sales in the banking industry. The study employed both descriptive and inferential statistics, the researchers formulated three hypotheses to serve as a guide in writing the paper. The researchers collected data from banks in Sango, Ogun State, Nigeria. The study revealed that building a longterm relationship with end-users of the product gives an organization competitive superiority which could positively influence their sales performance. The study recommended that the Nigerian Banking Industry should deliver quality service to their customers to forestall customer switching behavior. Quality delivery of services could lead to customer retention and thus profitability. Therefore, since two-way communication between a service provider and a customer is essential, active communication between both parties will foster better understanding and eradicate the incidence of customer switching behavior among mobile telecommunication service providers in Nigeria.

\section{Customer Retention}

Customer Retention can be defined as the likelihood of a client being maintained by the organization (Morgan \& Hunt, 1994). Customer retention could also mean upholding customers for life. The continuous existence and patronage of a customer in any business can turn around the profitability of a firm and offer it a competitive edge over other firms. Some studies see customer retention from a behavioral viewpoint. Thus, customer sensitivity is a major concern for a marketing firm. For example, the customer indorses the firm to other prospective customers through word-of-mouth which could results in new customer entrant into the company and ensures adequate repurchase. Customer retention is defined as the "customers" persistence of a business relationship with the firm. For mobile service providers, customer retention implies continuous and usage of a provider over a long period.

Year XXIV no. 80

June 2021 


\section{Customer Loyalty}

Customer loyalty is seen as a major business stratagem and extreme strength of a firm because it assures a business's success and enhances its level of viability. Therefore, creating and sustaining customer loyalty is crucial to the business. organizations should not assume that customer loyalty management is the same as customer management for cost-effectiveness. Loyal customers are well-thought-out as indispensable to a company's sales performance (Maghsoudi, 2003). Customer loyalty is referred to as the backbone for firms as it is a way for sustaining and increasing sales and due to its vital protagonist for intensifying profits. Reichheld \& Sasser (1990) opined that the expenditure of getting new customers is way higher than the cost of maintaining the current customers). These customers with whom the firm has maintained a good relationship stretched good word of mouth advertisement concerning the nature of services they receive from the company and this can attract prospective customers. (Ndubisi \& Kahraman, 2005).

\section{Relational Bonds}

The significance of relational bonds in long-term relationship building in marketing cannot be overemphasized. Liliindar and Strandivik (1995) assert that there exist varieties of relational bonds that can occur between a service provider and a customer. Lin, Weng, and Hsieh (2003) advocated that businesses can enhance the relationship with customers by taking advantage of these which include financial, social, and structural bonds (Berry and Parasuraman, 1991; Berry, 1995). Financial bonds have to do with the company's retention strategy of offering economic benefits like lowering prices and giving a discount to consistent customers to ensure repeat patronage (Berry and Parsuraman, 1991; Berry, 1995; Hsieh, Chiu and Chiang, 2005). Han (1991) illustrates social bonds as "the level bonds that bind a firm and customers together closely in a personal (emotional sense) like intimacy, acquaintance, social support or any other relational contact. Structural bonds, on the other hand, exist when a firm boosts customer relationships by providing answers to customer hitches by way of service delivery and other aspects the firm could assist the customer. (Lin, Weng, and Hsieh, 2003; Sheth and Parvatiyar, 2000). Tommie \& Martin (2017) in their study investigated the contexts within "sales and service" spheres that lead to customer satisfaction and also surveyed whether contented customer satisfaction in the "sales and service" spheres leads to a longlasting customer relationship for the car retailers. They formulated hypotheses based on extant literature and were developed into a projected framework. The research reveals that 60 percent of the interviewees incline to remain in a long-term customer relationship with the retailer that can meet their expectations. Also, that 
customers endure having confidence in a long-term customer relationship with the car retailers. They recommend that managers focus on methods and procedures that can grander immerse customer satisfaction all through the "sales and service" period. Susan (1995) researched customer switching behavior in service industries: An exploratory study. Susan observed that customer switching behavior has costly consequences on a company's market share and profitability. Simon (2012) researched on consumer's switching behavior: A theoretical review and research agenda. The article lengthily reviews the literature on theories of Consumer Switching Behaviour (CSB) and proposes an integrated model of CSB for elucidating the occurrence in the background of the mobile telecommunication industry in emerging countries. The proposed model encompasses the prevailing Push-Pull-Mooring Theory of consumer switching by combining the effect of government policy, switching intention abortion insufficiency as well as the psychological, emotional, and behavioral concern of switching on consumer and their previous and new service providers. They equally suggest future research to test the proposed model is suggested.

\section{Customer Switching Behaviour}

Product switching stems from customer change of loyalty from one supplier of product to another similar firm producing the same products. Brand switching behavior is a topical issue in marketing because of the effect of brand switching customer behavior on a firm (Bass, 1974). Switching intent is the inclination of a consumer to dismiss their relational bond with one firm to port to another firm producing a similar product (Chuang, 2011). Keaveney (1995) sees consumer switching behavior as a scenario where a customer favors another service provider different from their initial supplier. Brand switching among mobile network users is rampant and is a subject of concern because of the economic cost to the suppliers. Juan, Yolanda, and Fco.Javier (2006) researched the impact of customer relationship characteristics on customer switching behavior. Differences between switchers and stayers. They aimed to reveal how relationship marketing has acclaimed the relevance of building long-term relationships in enhancing firms' viability and assuring their future profitability. The study obtained data set used to carry out this study has been obtained from a panel survey (Home Online) of technology users in the United Kingdom, and the proposed hypotheses are tested on the fixed-line telephone sector using logistic regression. The results show that a deep relationship with customers can deter customers' propensity to switch fixed-telephone suppliers. Divine (2014) researched switching behavior and customer relationship management: the Iceland experience. The article accessed the reason behind customers switching from one supplier to another supplier and explain how long-

Year XXIV no. 80

June 2021 
term relationship building could reduce switching behavior especially in a competitive market where the tendency of customers to switch from one network service provider is high. The study revealed that food retailing is often neglected and underestimated. Besides building long-term customer relationships is often misconstrued and erroneously applied and this disallowed organizations from reaping the complete advantage it contains.

\section{Theoretical Framework}

This research is anchored on the Push-Pull-Mooring Migration Model of Ravenstein Ravenstein detected that human movement is motivated by push-pull consequences (Lee, 1966). Up to this time, this model is one of the widely accepted models used by scholars when discussing migration (Cohen, 1996). This model sees migration as the outcome of the collaboration that exists in the push upshot at the primary location and the pull consequences at the endpoint. Push effects are the unpleasant reasons why people will decide to quit a place, for instance, lack of opportunities, incessant war, community rivalries, terrorism, insecurity of life, and properties. While on the other aspect, the pull factor refers to what makes a place attractive for people to see as their final home destination (Lee, 1966). Though, the push-pull model fails to consider the individual movement of persons. Lee (1966) however, presented the idea of "mediating difficulties" and "individual factors" into the conversation of push-pull powers. Moon (1995) long-drawn out this Push-Pull model to integrate mooring perception, suggesting the PPM model to elucidate human migration. The PPM model is the central pattern in immigration write-up and prompts academics those human problems and social ethics are also significant influences in movement from one place to another (Bansal, Taylor \& James, 2005). The PPM model has attracted wide application in the field of marketing due to its significance in revealing the causes of migration which is similar to reasons for customers switching from one service provider to another service provider and what causes customers attraction from other service providers.

\section{Research Methodology}

The study adopted the survey research design. Adopting Multi-stage sampling, the population of this study includes all mobile telecommunication company and their subscribers in Edo State, Nigeria. The samples for this study were drawn from Mobile Network Service Providers and their subscribers. For service providers, three (3) out of the nine (9) mobile network operators were selected (Nigeria Communication Commission NCC, 2020). The three mobile network operators selected include - MTN, GLO, AIRTEL. The choice of the mobile network 
operators selected for this study was the fact that they both have a good number of subscribers and started business in Nigeria at almost the same time. Morgan and Krejcie's (1970) sampling methods were implemented to choose a sample of 322 mobile telecom subscribers Godden (2004). The paper employed regression analysis to analyze and test the hypothesis formulated. Edo State was chosen because customers of mobile network operators abound everywhere in the State. The instrument adopted to gather the needed data for this study is the questionnaire. Convenient sampling was later adopted to obtain information from the tertiary institution within Edo state. The institution selected includes Edo University Iyamho, Auchi Polytechnic, and Igueben college of Education. The above institutions were selected to represent the University, Polytechnic, and college of Education. The choice of a higher institution was to be able to obtain data from knowledgeable subscribers who were able to respond adequately to the questions.

The model for this study is formulated from the conceptual presentation of various determinants of long-term relationship building this model, therefore, stated functionally as Customer Switching Behaviour (CSB) $=\mathrm{f}($ Two-way communication (TC), Customer Retention Strategy (CRS), Customer Loyalty (CL), Relational Bond (RB).

$\mu=$ error term denoting other factors not captured in the functional relationship. The econometric model is derived thus:

$$
\mathrm{CSB}_{\mathrm{t}}=\propto_{o}+\propto_{1} \mathrm{TC}_{\mathrm{i}}+\propto_{2} \mathrm{CRS}_{\mathrm{i}}+\propto_{3} \mathrm{CL}_{\mathrm{i}}+\propto_{4} \mathrm{RB}_{i}+\mu_{i} .
$$

Where CSB, TC, CRS, CL, RB had been defined earlier.

$\propto_{1,}, \propto_{2}, \propto_{3}, \propto_{4}$ where the coefficients of the explanatory variables of interest to be estimated, $\mathrm{i}=$ is the number of respondent ranging from 1,2 ...........................n.

Apriori Expectation.

$\propto_{1}, \propto_{2}, \propto_{3}, \propto_{4}>0$

This research employed regression analysis with the aid of the Statistical Package for Social Science to test the hypothesis formulated. The table below displayed the pilot test conducted on the independent and dependent variables utilized in this study. The Cronbach alpha value for all the variables lies between 0.82 and 0.89 which is quite acceptable because in general the Alpha value of 0.7 is considered useful for any study.

Year XXIV no. 80

June 2021 
Table 1. Pilot test conducted on independent and dependent variables

\begin{tabular}{|c|c|}
\hline Variables & Cronbach's Alpha \\
\hline Two-way Communication & 0.85 \\
\hline Customer Retention & 0.85 \\
\hline Customer Loyalty & 0.89 \\
\hline Relational bonds & 0.82 \\
\hline Customer Switching Behaviour & 0.86 \\
\hline
\end{tabular}

\section{Research Findings}

\section{Descriptive Statistics of the Respondents}

To achieve the objective of this research, three hundred and twenty-two (322) questionnaires were administered to customers of mobile network service operators in other to elicit information from respondents. Out of the three hundred and twenty-two questionnaires administered, three hundred and five were returned filled and found sable for this study. This represents a 95\% response rate, therefore, 305 is the unit of analysis for this study. The demographic features of interest in this study are respondents' gender, marital status, age, educational qualification, Mobile network of use.

Table 2. Respondents' Demographic Information

\begin{tabular}{|l|l|l|l|}
\hline \multicolumn{1}{|c|}{ Variables } & \multicolumn{1}{|c|}{ Characteristics } & Frequency & \multicolumn{1}{c|}{ Percentage } \\
\hline Gender & $\begin{array}{l}\text { Male } \\
\text { female }\end{array}$ & 185 & $61 \%$ \\
& & 120 & $39 \%$ \\
\hline Total & & $\mathbf{3 0 5}$ & $\mathbf{1 0 0}$ \\
\hline Age & $18-20$ & 88 & 29 \\
& $21-25$ & 75 & 25 \\
& $26-35$ & 66 & 21 \\
& $36-45$ & 30 & 10 \\
Total & 46 and above & 46 & 15 \\
\hline Education Qualification & & $\mathbf{3 0 5}$ & $\mathbf{1 0 0}$ \\
& Below B.Sc./HND & 205 & 67 \\
& B.Sc./HND & 30 & 10 \\
& Master's Degree & 29 & 10 \\
& Ph.D. & 37 & 12 \\
\hline Total & Prof. & 4 & 1 \\
\hline Year XXIV no. 80 & & $\mathbf{3 0 5}$ & $\mathbf{1 0 0}$ \\
\hline
\end{tabular}




\begin{tabular}{|l|l|l|l|}
\hline \multicolumn{1}{|c|}{ Variables } & \multicolumn{1}{|c|}{ Characteristics } & Frequency & \multicolumn{1}{c|}{ Percentage } \\
\hline Marital Status & Single & 186 & 61 \\
& Married & 77 & 25 \\
& Separated & 42 & 14 \\
\hline Total & & $\mathbf{3 0 5}$ & $\mathbf{1 0 0}$ \\
\hline Type of Tertiary Institution & University & 151 & 50 \\
& Polytechnic & 100 & 33 \\
& College of Education & 54 & 17 \\
\hline Total & & $\mathbf{3 0 5}$ & $\mathbf{1 0 0}$ \\
\hline Respondents' Mobile & MTN & 133 & 44 \\
Network line & GLOBACOM & 93 & 30 \\
& AIRTEL & 79 & 26 \\
\hline Total & & $\mathbf{3 0 5}$ & $\mathbf{1 0 0}$ \\
\hline
\end{tabular}

Source: Author's fieldwork, 2020.

Table 2 above shows that a high percentage of the respondents are male with about $61 \%$ while the percentage of female respondents stood at 39\%. This implied that male folks' respondents were more in number than female respondents. For marital status, 186 respondents' representing $61 \%$ of the total respondents were single, 77 respondents representing $25 \%$ of the total respondents were married while $14 \%$ of the respondents were separated according to the data gathered. For educational qualification, the data gathered revealed that 205 respondents representing $67 \%$ of the total respondents were undergraduate, those with B.Sc./HND were $30(10 \%)$ of the total respondents, respondents with master's degree were $29(10 \%)$ of the entire respondents, respondents with Ph.D. were $37(12 \%)$ of the total respondents, the data equally revealed that 4 respondents were a professor and this represents $1 \%$ of the total respondents. A large percentage of respondents of about $67 \%$ without B.Sc./HND was anticipated because the research was carried out in tertiary institutions of which most of the respondents are pursuing one degree or the other. For the nature of the tertiary institution, 151 respondents representing $50 \%$ of the total respondents were from the University, 100 respondents representing $32 \%$ of the total respondents were from the Polytechnics while 54 respondents representing $18 \%$ of the total respondents were from the College of Education. For respondent's mobile network line, 133 respondents representing $44 \%$ of the total respondents subscribed to MTN, 93 respondents representing 30\% of the total respondents subscribed to GLOBACOM while 79 respondents representing $79 \%$ of the total respondents subscribed to AIRTEL. 


\section{Description of Dependent and Independent Variables}

The mean and standard deviation variables of interest in this study include customer switching behavior (CSB), two-way customer communication (TC), customer retention strategy (CRS), customer loyalty (CL), and rational bond.

Table 3. Description of research variables

\begin{tabular}{|l|l|l|l|}
\hline S/N & Statement & Mean & Standard Deviation \\
\hline \multicolumn{4}{|c|}{ Dependent Variable } \\
\hline 1 & \multicolumn{1}{|c|}{ Independent Variables } & 0.830 \\
\hline \multicolumn{4}{|c|}{4.04} \\
\hline 1 & Two-way Communication & 3.39 & 0.790 \\
\hline 2 & Customer Retention Strategy & 3.98 & 0.780 \\
\hline 3 & Customer Loyalty & 4.05 & 0.780 \\
\hline 4 & Relational bond & 4.06 & 0.790 \\
\hline
\end{tabular}

Source: Author's Computation, 2020.

The mean scores of 4.04 obtained in table 3 exceeded 3.0 revealing that a percentage of the respondents agreed with the items used in measuring customer switching behavior. Similarly, the mean score of the independent variables "long-term relationship building" shown in table 3 also revealed that the majority of the respondents agreed with the items used in measuring them as the values are greater than the mid-point of 3 .

\section{Model Estimation and Interpretation}

In other to estimate the model of regression specified for this study, multiple regression was conducted. The estimated model shows the relationship between the dependent variable and independent variables. The result is presented in Table 4 below:

Table 4. Relationships between Customer Switching Behavior and Long-term Relationship Building.

\begin{tabular}{|l|l|l|l|l|}
\hline Variables & Coefficient & Std Error & t-Statistics & Prob. \\
\hline C & 0.390525 & 0.215394 & 1.808455 & 0.0732 \\
\hline $\begin{array}{l}\text { Two-way } \\
\text { Communication (TC) }\end{array}$ & 0.282335 & 0.042350 & 6.74602 & 0.0000 \\
\hline
\end{tabular}

Year XXIV no. 80

June 2021 


\begin{tabular}{|l|l|l|l|l|}
\hline Variables & Coefficient & Std Error & t-Statistics & Prob. \\
\hline $\begin{array}{l}\text { Customer Retention } \\
\text { Strategy (CRS) }\end{array}$ & 0.232006 & 0.071308 & 3.258631 & 0.0013 \\
\hline Customer Loyalty (CL) & 0.222314 & 0.061418 & 6.836120 & 0.0000 \\
\hline Relational Bond (RB) & 0.263345 & 0.078650 & 7.862307 & 0.0000 \\
\hline R-Squared & 0.646408 & F-Statistics & 75.50927 \\
\hline Adjusted R-Squared & 0.637835 & Prob(F-Statistics) & 0.000000 \\
\hline Observation & 305 & Durbin-Watson Statistics & 1.774826 \\
\hline
\end{tabular}

The regression results in Table 4 show the relationship between customer switching behavior and long-term customer relationship. The independent variables were regressed on the dependent variable (customer switching behavior), the coefficient of determination $\left(\mathrm{R}^{2}\right)$ value stood at $65 \%$. The value of the Adjusted $\mathrm{R}^{2}$ of $64 \%$ shows that the independent variable (Two-way Communication, Customer retention Strategy, Customer Loyalty, and Relational Bond) jointly explained 64\% of the variation in the dependent variable - customer switching behavior. The result also showed that long-term relationship building (Two-way Communication, Customer retention Strategy, Customer Loyalty and Relational Bond) had a positive and statistically significant relationship with customer switching behavior in mobile network service at $\mathrm{p}>0.05$; this means that there exists a statistically significant relationship between the dependent and independent variables as a group. Besides, the Durbin-Watson statistics of 1.774826 suggest the absence of first-order serial correlation.

\section{Conclusion and Discussion}

This empirical research paper has established the association existing between longterm relationship-building customers and how it can help in preventing customer switching behavior in the Nigeria Telecom Sector. The findings of the study showed that a business entity needs adequate long-term relationship building to compete with others favorably and stay in business as this will help prevent customer switching behavior. As a contribution of this article, players in the telecom sector should encourage customers by strengthening long-term relationship building to benefit from word-of-mouth advertising which is capable of increasing their productivity and sales, improve on customer retention strategy, enhanced customer loyalty, and equally engage in relational bond with customers in a competitive market like the telecommunication industry.

This study, long-term relationship building and customer switching behavior in the Nigerian telecommunication industry attempted to explore the impact of 
relationship building over a long period with customers on customer switching behavior. The study's rationale for the choice of mobile subscribers as a population was the fact that mobile communication is now a cash cow business in Nigeria and a huge subscriber market exit which made the work easy to obtain the relevant data. The independent variables for this study were long-term relationship building decomposed into two-way communication, customer retention strategy, customer loyalty, and relational bond while the independent variable was customer switching behavior. All the dependent variables regressed with the dependent variable were statistically significant which implies that when a mobile network operator maintains two-way communication, adopt customers' retention strategy, enhance customer loyalty and engage in relational bond with customers, it will be difficult for customers to switch from their current service provider to another (customer switching behavior). The findings of this research corroborate with the findings of Lim, Yeo, Goh, \& Koh (2018) when they found word-of-mouth communication to be significantly related to consumer switching behavior in telecommunication in Malaysia as the p-value of word-of-mouth communication to customer switching behavior was 0.000 which is less than 0.05 . These research findings were also parallel with the previous research done by Liang, Ma, and Qi who researched Service quality and customer switching behavior in China's mobile phone service sector. Similarly, back here in Nigeria, Findings revealed that an organization requires relationship marketing to gain a competitive edge over rivalries, sales performance can be enhanced by way of building sound and long-lasting relationships with customers and other stakeholders in the business (Kehinde, Adegbuyi, \& Borishade, 2016). Mudassir and Waheed, (2015) conclude in their research that customer loyalty can be developed, strengthened, and preserved by marketing plans targeted at enhancing trust, exhibiting a commitment to service, communicating with customers in an appropriate, reliable and preemptive manner, and tackling discrepancy proficiently. The above author's conclusion coincides with the findings of this paper with a significant relationship that exists between long-term relationship building and customer switching behavior in the Nigeria Telecommunication Industry. Finally, the work of Tommie and Martin (2017) on long-term customer relationship: A study on how to achieve long-term customer relationship in the car retail sector further show that $60 \%$ of the respondents interviewed are enthusiastic about keeping a long-term customer relationship with the retailer that can meet their expectations. This agrees with the findings of this work that building customer loyalty, retention strategy, proper communication, and engaging in relational bond with customers enhanced long-standing relationship with both parties and on the long-run impact on the productivity and profitability of the business.

Year XXIV no. 80

June 2021 
The Push-Pull-Mooring Migration Model makes available so many insights into this research paper. This model unveils what factors can push customers to patronizing other organizations as well as factors that can pull customers to a firm for continuous patronage. The research utilizes this theoretical finding to contribute meaningfully in diverse ways to the contemporary literature on long-term customer relationship building and customer switching behavior. The verified hypotheses in this study contributed to the theory-building since it is fundamental for well-known theories to endure pragmatic analysis through time and scope, to remain germane to organizations, registered firms, and the public. This research offers vibrant information for managers in the telecommunication industry as well as managers in the field that are related to building a long-lasting relationship that will result in a win-win situation for both parties - the firms and its customers. In marketing, wordof-mouth publicity is fundamental to the success or failure of a firm depending on whether such publicity is positive or negative for the firm. This study will enable telecommunication firms to realize the impact of building a sustainable relationship with customers and the attendant publicity that could emanate from such an endeavor. Again, customer switching behavior could be controlled by firms through the demands of this study, firms who can engage the variables used in this study and turn their business around for the better.

The study, therefore, recommends the following:

i. The players of the mobile telecommunication Industry (mobile network service) should embrace the application of long-term relationship-building to achieve, sustain and retain customers' usage of their products, this will enable them to compete better with other players in the industry.

ii. The players of the mobile telecommunication Industry (mobile network service) should engage in relational bonding aimed at creating attachment with the customer that could result in customer retention and subsequently profitability.

iii. The players of the mobile telecommunication Industry (mobile network service operators) should improve on relationship marketing in other to enable them to manage competition effectively.

iv. The players of the mobile telecommunication Industry (mobile network service providers) should engage in two-way communication continuously with their subscribers to know factors that could make them switch to their competitors and make adequate amendments beforehand.

v. The players of the mobile telecommunication Industry (mobile network service providers) should see the issue of long-term relationship building with their customers as a strategic business strategy that will help facilitates the growth of their business. 


\section{Limitation}

This research has several shortcomings. To begin, the questionnaire used as a means for investigation may not provide a concise view of long-term relationship building and customer switching behavior. Second, the study was conducted in certain cities in Edo State, Nigeria. Drawing research inferences to the whole cities in Nigeria is inadequate. Third, this research only looked at the mobile telecommunication industry, other sectors may give uncommon results. For future study, the study can apply a more qualitative approach to deeply access long-term relationship building and consumer switching behavior in the food and beverage industry. Also, the study should be conducted over a large spectrum of cities to preclude the research dominance in a single city. Third, future studies should employ other statistical tools for analysis instead of regression analysis as well as search for other elements that may prevent consumer switching behavior can be included too.

\section{References}

Bansal, H.S., Taylor, S.F. \& James, Y.S. (2005). 'Migrating' to new service providers: Toward a unifying framework of consumers' switching behaviors. Journal of the Academy of Marketing Science, 33(1), 96-115.

Bass, F.M. (1974). The Theory of Stochastic Preference and Brand Switching. Journal of Marketing Research, 11, 1-20. https://doi.org/10.2307/3150989

Berry, L. L. (1995) Relationship marketing of services-growing interest, emerging perspectives. Journal of the Academy of Marketing Science, 23(4), 236-245.

Berry, L. L. (2002). "Relationship Marketing of Services Perspectives from 1983 and 2000". Journal of Relationship Marketing. 1 (1): 59-77. doi:10.1300/j366v01n01_05. ISSN 1533-2667. S2CID 167676460.

Berry,L,L. \& Parasuraman, A.Q. (1991). Marketing services. New York, The Free Press

Chuang, Y. F. (2011). Pull-and-suck effects in Taiwan mobile phone subscribers switching intentions. Telecommunications Policy, 35(2), 128-140.

Cohen R. (1996). Theories of migration. London: Cheltenham Publish.

Divine, M. A. (2014). Switching behavior and customer relationship managementthe Iceland experience. British Journal of Marketing Studies. 2(1), 89-100.

Esther, A., Audu, M., \& Murtala, S. S. (2019). Factors influencing brand switching behavior of mobile phone users and the mediating effect of customer satisfaction: a literature review. Joumal of Education, Society and Behavioural Sciences, (29)1, 1-11.

Godden, B. (2004). Sample size formula. Journal of Statistics, 3(66).

Year XXIV no. 80

June 2021 
Gourvile, T. J. (2003) Why consumers don't buy: Psychology of new product adoption, Harvard Business School Case. 504-056, (http: harvardbusinessonline. hbsp.harvard.edu/b02/en/common/item).

Han, S., (1991). Antecedents of buyer-seller long-term relationships: An exploratory model of structural bonding and social bonding, Doctoral Dissertation. Department of Marketing. The Pennsylvania State University.

Hsieh,Y., Chiu, H., Chiang, M. (2005). Maintaining a committed online customer: A study cross search-experience-credence products. Journal of Retailing, 81(1), 75-82.

Juan, P. M. L., Yolanda, P.R., \& Fco. Javier, S. O. (2006). The impact of customer relationship characteristics on customer switching behavior. Differences between switchers and stayers. Managing Service Quality. 16 (6), 556-574. DOI 10.1108/09604520610711909.

Keaveney, S. M. (1995). Customer switching behavior in service industries: An exploratory study. The Journal of Marketing, 59(2):71-82.

Kehinde, O. J., Adegbuyi, A. O. \& Borishade, T. T. (2016). Relationship marketing: The antidote for effective sales performance in the Nigerian Banking Industry. Research journals of Management, 4(2), 1-11.

Krejcie, R. V., \& Morgan, D. W. (1970). Determining sample size for research activities. Educational and Psychological Measurement, 30(3), 607-610. doi:10.1177/001316447003000308

Lee, E.S. (1966). A theory of migration. Demography, 3(1), 47-57.

Liang D, Ma Z, Qi L. (2013). Service quality and customer switching behavior in China's mobile phone service sector. Journal of Business Research, 66(8), 1161-1167.

Liljander, V., \& Strandvik, T. (1995). The nature of customer relationships in services. Advances in Services Marketing and Management, 4, 141-167.

Lim, K. B., Yeo, S. F., Goh, M. L., \& Koh, W. M. (2018). A study on consumer switching behavior in the Telecommunication industry. Journal of Fundamental and Applied Sciences. 10(6S), 1143-1153.

Lin, P., Weng, J. C. M., Hsieh, Y. (2003). Relational bonds and customer's trust and commitment- a study on the moderating effects of web site usage. The Services Industries Journal, 23 (3), 103-127.

Liu, Y., Tao, L., Li, Y., \& El-Ansary, A. (2008). The impact of a distributor's trust in a supplier and use of control mechanisms relational value creation in marketing channels. Journal of Business \& Industrial Marketing, 23, 12-22.

Maghsoudi, M. H. (2003). The relationship between customer satisfaction with the efficiency and effectiveness of processes. Proceedings of the Fourth Conference of Quality Management, Iran. 
Moon, B. (1995). Paradigms in migration research: exploring 'moorings' as a schema. Progress in Human Geography, 19(4), 504-24.

Morgan, R.M. \& Hunt, S. D. (1994). The commitment-trust theory of relationship marketing. Journal of Marketing. 58(3), 20-23.

Mudassir, H. \& Waheed, M. A. (2015). Relationship marketing and customer loyalty: Evidence from the banking sector in Pakistan. Global Journal of Management and Business Research, 15(10), 1-12.

Ndubisi, N.O., \& Kahraman, C. (2005). Teleworking adoption decision-making processes: multinational and Malaysian firms' comparison. Journal of Enterprise Information Management, 18(2), 150-68.

Nigeria Telecommunication Commission (2020). Telecom subscribers hit 187.4 million in February 2020. https://techeconomy.ng/2020/05/ncc-telecomsubscribers-hit-187-4-million-in-february-2020.

Padmavathy, C., Balaji, M. S., \& Sivakumar, V. J. (2012). Measuring the effectiveness of customer relationship management in Indian retail banks. International Journal of Bank Marketing, 30(4), 246-266, https://doi.org/ 10.1108/02652321211236888

Reichheld, F.F., \& Schefter, P. (2000). E-loyalty: Your secret weapon on the web. Harvard Business Review, 78(4), 105-13.

Sheth, J. N., \& Parvatiyar, A. E., (2000). Handbook of relationship marketing, Sage Publication Ltd, London.

Simon, G. N. (2012). Consumer switching behavior: A theoretical review and research agenda. Research Journal Social Sciences and Management, 2(3), 78 -81.

Staden, Van., Marx, E, S. \& Erasmus-Kritzinger, L (2002). Corporate Communication - Getting the Message Across in Business. Pretoria: Van Schaik Publishers.

Susan, M. K. (1995). Customer switching behavior in service industries: An exploratory study. Journal of Marketing, 59(2), 71-82.

Tommie, A., \& Martin, L. (2017). Long-term customer relationship: A study on how to achieve long-term customer relationship in the car retail sector. Jonkoping International Business School. 1 - 51.

Velnampy, T. \& Sivesan, S. (2012). Customer relationship marketing and customer satisfaction: A study on mobile service providing companies in Srilanka. Global Journal of Management and Business Research, 12(18), 1-7.

Year XXIV no. 80

June 2021 